\title{
Studies on glycoproteins of the human seminal plasma1)
}

\author{
By W. P. Herrmann and G. Uhlenbruck \\ with technical assistance of I. WEYLAND \\ Hautklinik (Direktor: Prof. Dr. G. K. Steigleder) and Medizinisclbe Klinik (Direktor: Prof. Dr. R. Gross) \\ der Universität Köln
}

(Eingegangen am 7. März 1972/15. Mai 1972)

Lectins and protectins, i. e. heterophile antibody-like reagents occurring in plants and invertebrates, are known to rcact specifically with certain terminal non-reducing carbohydrate residues and/or inner chain sugar units of glycoproteins and glycolipids.

A total of 15 such substances were used for the demonstration and characterization of glycoproteins present in the human seminal plasma.

Double diffsuion tests revealed at least 6 different glycoproteins; most of them are heat-stable. Two of these glycoproteins were shown to originate in the prostate gland since they could be demonstrated in the seminal plasma of a patient with bilateral occlusion of the ampullae. $\beta$-D-Galactosyl groups, $\mathrm{N}$-acetyl-D-galactosamine and $\mathrm{N}$-acetyl-neuraminic acid were found as terminal carbohydrate residues.

$\mathrm{N}$-acetyl-D-glucosamine was also demonstrated as an inner chain sugar unit. In addition, it was shown that one of the seminal plasma glycoproteins with a terminal $\mathrm{N}$-acetyl-neuraminyl group also contained $\mathrm{N}$-acetyl-galactosamine, the latter being unmasked after treatment with neuraminidase.

Moreover, it was found that two protectins and a lectin, all of which are known to react with blood group substance A on account of their specifities for terminal galactosaminyl groups, developed precipitation lines with a non-dialyzable and heat-stable glycoprotein of the seminal plasma.

Lektine aus Pflanzen und Protektine von wirbellosen Tieren sind heterophile antikörper-ähnliche Substanzen, die mit bestimmten endständigen, nicht-reduzierenden Kohlenhydratgruppen und mittelständigen Zuckerbausteinen von Glycoproteinen und Glykolipiden zu reagieren vermögen.

Mit insgesamt 15 derartiger Substanzen wurden die Glycoproteine des menschlichen Spermaplasma analysiert. Im OuCHTERLONY-Test konnten mindestens 6 verschiedene Glycoproteine zur Darstellung gebracht werden, die sich zum größten Teil als hitzestabil erwiesen. Zwei dieser Glykoproteine stammen vermutlich aus der Prostata, da sie auch im Ejakulat von Patienten mit doppelseitigem Verschluß der ductus ejaculatorii vorkommen.

An endständigen Kohlenhydratgruppen fanden sich $\beta$-D-Galaktosylgruppen, N-Acetyl-D-Galaktosamin und N-Acetylneuraminsäure, als mittelständiger Zuckerbaustein wurde N-Acetyl-D-Glucosamin nachgewiesen.

Eines der Glykoproteine mit endständiger N-Acetylneuraminsäuregruppe enthält zudem auch N-Acetyl-Galaktosamin, das jedoch erst nach Behandlung mit Neuraminidase nachgewiesen werden kann. Außerdem hat sich gezeigt, daß zwei Protektine und ein Lektin, die aufgrund ihrer Spezifitāt für endständige Galaktosamin-Gruppen mit der Blutgruppensubstanz A reagieren, ein nicht dialysierbares, hitzestabiles Glykoprotein des menschlichen Spermaplasma zu präzipitieren vermögen.

The antigen pattern of the human seminal plasma has been investigated in recent years by several authors (1). Numerous blood serum proteins as well as proteins secreted by the male accessory organs of reproduction have been identified (2). Certain characteristics of some of the latter proteins have been demonstrated with immunological and biochemical methods $(1,3,4-7)$. Little is known, however, about seminal plasma glycoproteins although these proteins give the male accessory fluids their mucous consistency (8). Earlier investigations showed that the human seminal plasma contains several fractions stainable with PAS (9) and the NADr reagent (10), but only two of the proteins precipitated by rabbit antisera specifically directed against human seminal plasma proteins stained like glycoproteins (3, 11). Since most human glycoproteins contain $\mathrm{N}-$ acetylneuraminic acid HerrmanN (12) investigated the effect of neuraminidase on seminal plasma proteins; he found that several enzymes and the $1.1 \mathrm{~S}$-protein secreted by the prostate gland as well as a protein designated $\mathrm{B}_{1}$ (according to his nomenclature) originating in the seminal vesicles are glycoproteines.

It is well established that the seminal plasma of secretors contains blood group substances that are known to be mucoids reacting with heterophile agglutinins $(13,14)$. It seemed reasonable, therefore, to make use of lectins and protectins for the characterization and identification of seminal plasma glycoproteins which till now have not been demonstrated by other immunological methods.

Lectins are heterophile agglutinins of plant origin which react specifically with certain terminal nonreducing carbohydrate residues and/or inner chain sugar units of glycoproteins and glycolipids. Some of the lectins have been found to possess precipitating properties. Their specifities have been described in numerous papers concerning the chemical nature of blood group active substances (see Tab. 1).

1) This investigation was supported in part by the Deutsche Forschungsgemeinschalt. 
Tab. 1

Lectins, protectins, and polymers

\begin{tabular}{|c|c|c|}
\hline No. & Substances & Specifity, References \\
\hline & Lectins & \\
\hline 1 & Waxbean & Gal (15) \\
\hline 2 & Phaseolus lunatus & GalNAc $(17,18,19)$ \\
\hline 3 & Ricinus communis & Gal $(20,21)$ \\
\hline 4 & Evonymus europaeus & Fuc $\left.(22)^{1}\right)$ \\
\hline 5 & Vicia graminea & GalNAc, Gal (?) (23) \\
\hline \multirow[t]{2}{*}{6} & Triticum vulgare & \\
\hline & (WGL $1 \%)$ & GlcNAc (24) \\
\hline 7 & Soja hispida & GalNAc $(23,25)$ \\
\hline 8 & Robinia $0,25 \%$ & Gal (?) $\left.(26)^{2}\right)$ \\
\hline \multirow[t]{2}{*}{9} & Concanavalin A & Man, Glc, Fru, GlcNAc $\left.(28,29,30)^{3}\right)$ \\
\hline & Protectins & \\
\hline 1 & Anti-AFH $5 \%$ & GalNAc, GIcNAc $(31,32,33)$ \\
\hline 2 & Anti-A $\mathbf{P}$ & GalNAc, GlcNAc, Glc $(31,32,34,35)$ \\
\hline 3 & Achatina granulata $10 \%$ & NA $\left.(36)^{4}\right)$ \\
\hline 4 & Achatina Chamaeleon $5 \%$ & ?4) \\
\hline 5 & Rapana thomasiana $1 \%$ & $\left.(37)^{5}\right)$ \\
\hline \multirow[t]{2}{*}{6} & Limulus polyphemus & NA $(38,39)$ \\
\hline & Basic polymers & - \\
\hline 1 & Lysozyme $1 \%$ & ) \\
\hline 2 & Protamine $1 \%$ & $(40,41)$ \\
\hline 3 & Poly-L-lysine & \\
\hline 4 & Polybrene $0,1 \%$ & \\
\hline
\end{tabular}

1) Kindly provided by Prof. O. PROKOP and Dr. R. KIRST, Berlin, GDR.

2) Kindly provided by Prof. R. BOURILlon and Dr. J. FONT, Paris.

3) Kindly provided by Dr. H. J. PARDOE, Birmingham.

) Kindly provided by Dr. O. BraIN and H. J. GRACE, Durban, South Africa.

5) Kindly provided by Prof. O. PRoKop, Berlin, GDR.

Abbreviations: Fuc $=\mathrm{L}$-fucose; $\mathrm{NA}=\mathrm{N}$-acetyl-neuraminic acid.

Protectins are agglutinating and occasionally precipitating glycoproteins of antibody-like character occurring in the albumin glands of snails, in the eggs of numerous fishes, and in the hemolymphe of invertebrates.
These protectines also react with certain carbohydrate structures on cell membranes of human, animal, and bacterial origin.

\section{Materials and Methods}

Semen was obtained by masturbation from bealthy donors. Samples were centrifuged at 2500 r.p.m. for $20 \mathrm{~min}$. Seminal plasma was separated, then stored at $+18^{\circ} \mathrm{C}$. Immediately before our experiments 12 samples were thawed and pooled. Another sample was obtained from a patient with aspermia as a consequence of bilateral occlusion of the ampullae. Lectins and protectins as summarized in Table 1 had been prepared by saline extraction as described elsewhere (see Tab. 1). Lysozyme was purchased from Koch-Light Lab. (Great Britain), polybrene from EGA Chemie (Steinheim, GFR), poly-L-lysine from Schuchardt (München, GFR), and neuraminidase from Serva and Behringwerke, Marburg/Lahn (GFR).

Double diffusion technique in agat gel according to OuchrerLoNy (42). Staining for proteins with azocarmine as described by URIEL (43).

\section{Results}

\section{Lectins}

With untreated human seminal plasma 7 out of the 9 lectins tested (No. 1-7) formed one or two distinct precipitation lines, giving a total of 13 precipitates (Tab. 2). Only two of these precipitation lines stained with azocarmine as do proteins; two others stained wealily, but most of them did not take up the dye. One of the two components precipitated by lectin No. 4 and one of the two precipitated by No. 5 gave complete identity reactions.

With seminal plasma that had been dialyzed against buffered saline only 5 of the lectins tested (No. 1, 2, 3,

Tab. 2

Precipitation reactions obtained by double diffusion in agar gel with pretreated and untreated human seminal plasma using various lectins, protectins, and anionic polymers

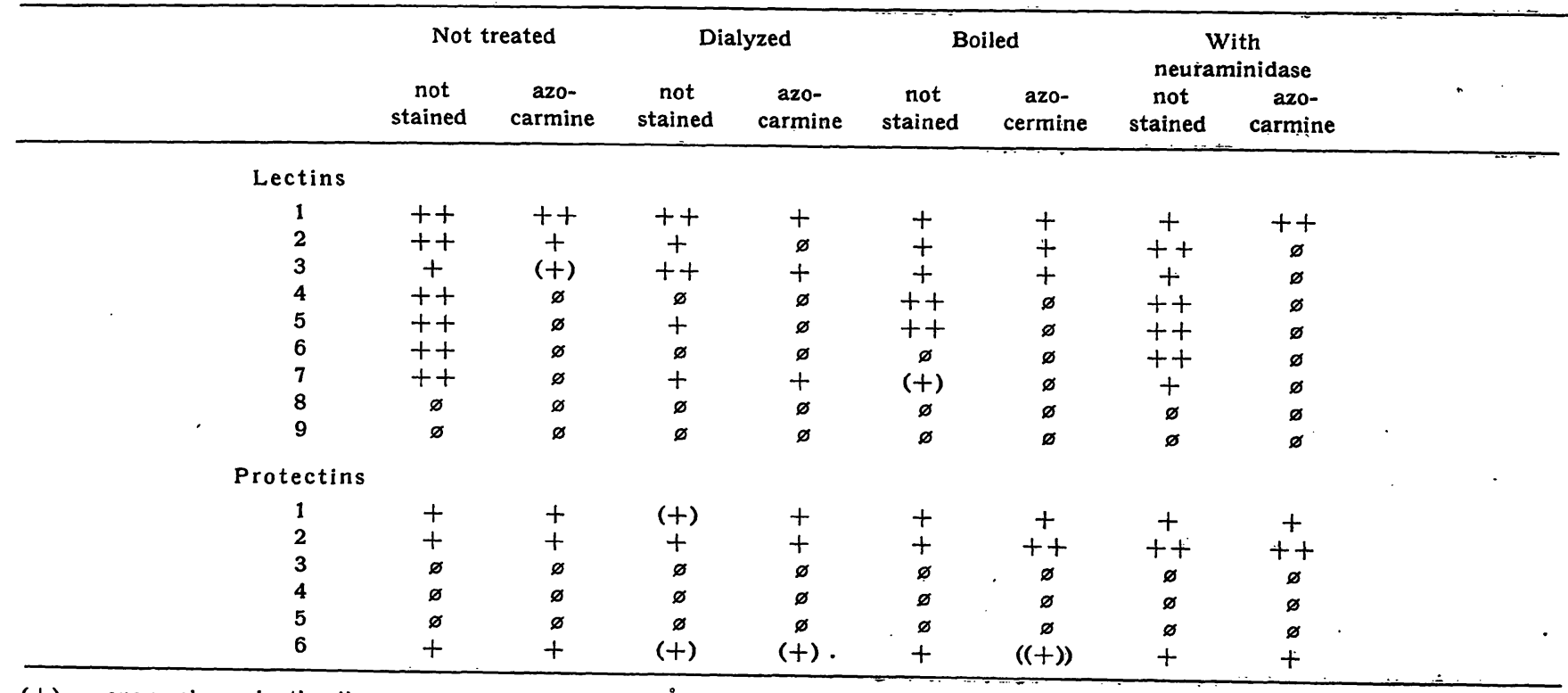

$(+)=$ one weak precipation line

$+\quad=$ one distinct line

$++=$ two distinct precipitation lines 
$5,7)$ gave a total of 7 precipitation lines, two of which stained with azocarmine.

It should be noticed that lectin No. 3 gave only one precipitate before but two precipitation lines after dialysis of seminal plasma.

Boiled seminal plasma reacted with 6 lectins (No. 1-5, 7) forming a total of 8 precipitation lines, but only three of them stained with azocarmine.

When seminal plasma was treated with neuraminidase, lectins No. $1-7$ formed a total of 11 precipitates, but only two of them - both reacting with lectin No. 1 - stained with azocarmine.

\section{Protectins}

Six protectins were tested (see Tab. 2). Three of them (No. 1, 2, 6) reacted with untreated human seminal plasma forming a single precipitation line stainable with azocarmine. The precipitate formed by protectin No. 6 was much weaker after dialysis of the seminal plasma, whereas those precipitates formed by protectins No. 1 and 2 remained unaffected. With boiled and neuraminidase-treated seminal plasma, protectin No. 2 formed two precipitates, indicating that the reacting components had undergone some change by these procedures. The components precipitated by protectins No. 1 and 2 gave a complete identity reaction. These components were found to be different from that precipitated by protectin No. 6 , which lay very close to the well containing the Limulus extract.

\section{Basic polymers}

When the basic polymers No. $1-4$ were tested against untreated, dialyzed, boiled, and neuraminidase-treated seminal plasma no precipitation reactions occurred.

In addition, lectins No. 1 and 2 and protectins No. 1, 2, and 6 were tested against ejaculate from a patient with bilateral occlusion of the ampullae. It was found that lectin No. 2 and the protectins No. 1 and 2 did not react with this sample. Lectin No. 1, however, developed a single distinct precipitation line and protectin No. 6 gave a rather strong precipitate similar but somewhat weaker than that formed with pooled normal seminal plasma.

\section{Discussion}

During the last decade lectins from plants and protectins from invertebrates have been widely used for the detection of carbohydrate-containing structures on cell membranes of various origins.

Most of this work has been based on the agglutinating properties of these antibody-like substances which combine selectively with certain sugar components.

It has also been shown that at least some of them are able to precipitate soluble glycoproteins.

The available data makes it abundantly clear that lectins and protectins are specifically and exclusively directed against terminal non-reducing carbohydrate residues and/or inner chain sugars but are, as a rule, independent of molecular size, carbohydrate / protein ratio, and antigenicity of their reactants. Thus, lectins and protectins offer a chance to characterize carbohydrate-containing constituents of the human seminal plasma that have not yet been demonstrated immunologically.

The results of earlier investigations on mucoids and blood group substances (31) suggested that the double diffusion technique according to OuCHTERLONY would be a suitable method for our purpose. This assumption was confirmed by the results of our present study, since 7 out of 9 lectins and 3 out of 6 protectins tested formed precipitation lines with several components of the untreated human seminal plasma. Some of these components were found to be dialysable, whereas others were not. These findings indicate that they are of different molecular size.

It was found that the precipitates formed by protectins and several lectins stain with azocarmine; this finding indicates that they react most probably with glycoproteins. The fact that most of them were heat-stable supports this view.

Other precipitates developed by lectins did not stain with azocarmine. It may be concluded, therefore, that the protein content of the latter ones is probably rather low.

With regard to earlier investigations performed by one of the authors (G. U.) it may be concluded that there are several glycoproteins present in the human seminal plasma containing the following terminal carbohydrate residues:

$\beta$-D-galactosyl group indicated by lectins No. 1, 2; $\mathrm{N}$-acetyl-galactos- indicated by lectins No. 2, 5, 7; amine

$\mathrm{N}$-acetyl-neuraminic acid protectins No. 1, 2;

indicated by lectin No. 6

It is interesting to note that the reaction of the Limulus polyphemus precipitin (No. 6) did not disappear completely when the seminal plasma had previously been incubated with neuraminidase.

This may be explained by the fact that only $70 \%$ of the $\mathrm{N}$-acetylneuraminic acid present in the human seminal plasma is released after treatment with neuraminidase (44).

Our finding that neuraminidase-treated seminal plasma formed two precipitation lines with protectin No. 2 whereas untreated seminal plasma formed only one, is due to an unmasking of new $\mathrm{N}$-acetylgalactosamine $(31,45)$.

N-acetyl-D-glucosamine which reacts with lectin No. 6 and protectin No. 2 has been found to occur as an inner chain sugar unit of seminal plasma glycoproteins.

The so-called Con A agglutinin receptor recently found on the acrosome of mouse spermatozoa (30) has also 
been shown to be present in the human seminal plasma by the hemagglutination inhibition technique; it does not precipitate human seminal plasma components.

Protectins No. 1 and 2 as well as lectin No. 2 are known to react with blood group substance A receptors as has been shown by Prokop et al. $(46,47)$.

Our expectation that these heterophile reagents would form corresponding precipitation lines with pooled human seminal plasma could be confirmed.

Protectins No. 3 and 5, however, both agglutinating red blood cells of various blood groups on account of their antineuraminyl-specifity $(36,37)$, did not precipitate any seminal plasma constituents.

A component precipitated by lectin No. 1 and another one precipitated by protectin No. 6 were found in the ejaculate of a patient with bilateral occlusion of the ampullae. It may be concluded, therefore, that these two components were secreted by the prostate gland, since this pathological sample did not contain any cellular and soluble secretion products originating in the testes, epididymis, or seminal vesicles.

High molecular basic polymers that have been shown to aggregate various mammalian cells and to precipitate soluble acid glycoproteins (40) did not form precipitation lines with human seminal plasma. So far, nonspecific precipitation reactions could be ruled out.

A close analysis of Table 2 reveals that we were able to demonstrate the presence of at ledst 6 different glycoproteins. As far as components reacting with the lectins are concerned, there must be at least 4 different glycoproteins, since the two components precipitated by lectin No. 1 stained with azocarmine whereas the two precipitated by lectins No. 4 to 7 did not. Among those reacting with protectins one glycoprotein with bloodgroup A reactivity was demonstrated with protectins No. 1 and 2. Protectin No. 6, however, precipitated quite another glycoprotein with a very small molecular size. It may well be that some of these glycoproteins act as spermatozoa-coating antigens.

\section{References}

1. Herrmann, W. P. (1969), Andrologie, 1, 11-18. - 2. Herrmann, W. P. \& Hermann, G. (1969), Arch. Klin. Exp. Derm. 234, 100-116. - 3. Hekman, A. \& Rümke, Ph. (1968), The antigens of human seminal plasma. Proc. XVI th Annual Collog. Protides of Biological Fluids, Bruges, Vol. 16. - 4. Herrmann, W. P. (1968), Arch. Klin. Exp. Derm. 233, 269-276. - 5. Hirsch-Marie, H. \& Conte, M. (1967), Bull. Soc. Chim. Biol. 49, 147. - 6. Herranann, W. P. (1971), Immunolog. Darstellung enzymatisch aktiver Proteine im menschlichen Spermaplasma. Fortschr. d. Fertilitätsforschg., Berlin, Vol. 2. - 7. Ewrew, T. (1970), this J. 8, 504-506. - 8. MaNN, TH. (1964), The Biochemistry of semen and of the male Reproductive tract. Methuen \& Co. Ltd. London/New York. - 9. Schnerder, W. C., NowakowsKI, H. \& VoIGT, K. D. (1954), Klin. Wochenschr. 32, 803. - 10. Hermann, G., Licht, W., Keutel, H. J. \& Krug, E. (1958), Z. Exp. Med. 130, 436. - 11. Licht, W. \& Keutex, H. J. (1963), Z. Urol. 56, 401. - 12. HerrmanN, W. P., Arch. klin. exp. Derm., in press. - 13. HartmanN, G. (1941), Group antigens in human organs. Munksgaard Publ. Copenhagen. - 14. Rangnekar, K. N. \& RAO, SH. S. (1970), Int. Arch. Allergy 37, 49. 15. Wintzer, G., Uhlenbruck, G., Schumacher, K., Alzer, G., Pardoe, G. I., Sprenger, I., OerkermanN, H. \& HirschmanN, W. D. (1971), Zur chemischen Natur des PHAErythroagglutinin-Rezeptors. in: G. Brittinger u. H. J. Roggenbach: Leukozytenkulturen. F. K. Schattauer-Verlag, Stuttgart. 16. Catsimporlas, N. \& Meyer, E. W., (1969), Atch. Biochem. Biophys. 132, 279. - 17. W IENER, A. S., MOOR-JANkowskI, J. \& Gordon, E. B. (1969), Int. Arch. Allergy 36, 582. - 18. UhLENBRUCK, G. \& SPRENGER, I. (1970), Vox sang. 19, 530. - 19. Salomon, J. M. \& Rosenberg, M. B. (1968), Bibl. haemat. 29, 202. - 20. Drysdale, R. G., Herrick, P. R. \& Franks, D. (1968), Vox sang. 15, 144. - 21. Pardoe, G. I., Brrd, O. W. G. \& UhLENBRUCK, G. (1969), Z. Immunitätsforsch. Exp. Ther. 137, 442. - 22. KRüPE, M. (1969), Die Blutgruppen des Menschen, Selbstverlag Fulda. - 23. Dahr, W. \& UHLENBRUCK, G. (1971),
Blut, 22, 128. - 24. Uhlendruck, G., Gielen, W. \& Pardoe, G. I. (1970), Z. Krebsforschg. 74, 171. - 25. UHLENBRUCK, G. \& DAHR, W. (1971), Vox sang. 21, 338. - 26. LESENEY, A. M., Font, J., Bourillon, R., SPrenger, I., VolgtmanN, R. \& UHLENBRUCK, G. (1971), Z. Naturforsch. B 26, 172. - 27. Bourrllon, R. \& Font, J. (1968), Biochim. Biophyṣ. Acta 154, 28. - 28. LroÝ, K. O. (1970), Arch. Biochem. Biophys. 137, 460. - 29. So, L. L. \& GoldsteIn, I. J. (1967), J. Immunol. 99, 158. - 30. Edelman, G. M. \& Milette, C. F. (1971), Proc. Nat. Acad. Sci., USA 68, 2436. - 31. Uhlenbruck, G., Pardoe, G. I. \& Prokop, O. (1970), Fortschr. Hämatologie, Vol. I, 71. 32. Prokop, O. \& UhleNBRUCK, G. (1970), Fortschr. Hämatologie, Vol. I, 17. - 33. UhLENBRUCK, G., SPRENGER, I., LESENEY, A. M., Font, J. \& Bourillon, R. (1970), Vox șang. 19, 488. 34. Hammarström, S. \& Kabat, E. A. (1971), Biochemistry 10 , 1684. - 35. IshiYAMA, I. \& UHLENBRUCK, G. (1971), Z. Naturforsch. B 26, 1198. - 36. UHLENBRUCK, G. (1969), J. Forens. Med. 16, 35. - 37. Popwassilew, I., Rackwitz, A. \& Prokop, O. (1970), Z. Immunitätsforsch. 139, 372. - 38. CoHEN, E. (1968), Exp. Ther. Transact. N. Y. Acad. Sci. II, 30, 427. - 39. UhreNBRUCK, G. \& GIELEN, W. (1970), Fortschr. Neurol. 38, 202. 40. Voigtmann, R. \& Uhleniruck, G. (1970), Thrombos. Diathes. Haemorrh. 24, 530. - 41. UHLENBRUCK, G., WINTZER, G. \& WeRsDörfER, R. (1967), this J. 5, 281-287. - 42. OuCHTHERLONY, O. (1948), Arkiv Kemi 26 B, 1. - 43. URIEL, J. (1960), Les réactions de charactérisation des constituants protéiques après éléctrophorèse ou immuno-éléctrophorèse en gélose. In: Grabar, P. et P. Burtin, Analyse immuno-électrophorétique Masson $\&$ Cie, Paris. - 44. Hirschin̈user, C., Milbradt, R. \& Kionke, M. (1971), Andrologie 3, 121. - 45. GotrsChalK, A., SCHAUER, H. \& Uhlendruck, G. (1971), Hoppe Seylet's Z. Physiol. Chem. 352, 117. - 46. Prokop, O., Uhlendruck, G. \& Köhler, W. (1968), Vox sang. 14, 321. - 47. Pardoe, G. I. \& Uhlendruck, G. (1970), J. Med. Lab. Technol. 27, 249.
Prof. Dr. W. P. Herrmann Univ.-Hautklinik Köln Prof. Dr. G. Uhlenbruck 2. Mediz. Univ.-Klinik Köln 5 Köln 41 Josef Stelzmannstr. 9 